\title{
PENGARUH BUDAYA ORGANISASI TERHADAP KINERJA PEGAWAI PADA CV. SRIWIJAYA UTAMA DI BANDAR LAMPUNG
}

\author{
Ariandini $^{(1)}$, Trisnowati Josiah ${ }^{(2)}$, Husna Purnama ${ }^{(2)}$ \\ Fakultas Ekonomi Universitas Sang Bumi Ruwa Jurai \\ dini_ariandini@gmail.com,trisnowati.josiah@fe.saburai.ac.id, husna.purnama@fe.saburai.ac.id
}

\begin{abstract}
Abstrak. Budaya organisasi adalah seperangkat nilai yang mengendalikan interaksi antara suatu individu dalam organisasi dengan individu lain dalam organisasi, atau organisasi lain sebagai pemasok, dan anggota masyarakat yang dilayani. Budaya organisasi dibentuk oleh para individu dalam organisasi, etika organisasi yang dianut, hak kepegawaian yang diberikan kepada tiap pegawai dan juga jenis struktur organisasi itu sendiri. Tujuan dari penelitian ini adalah untuk mengetahui pengaruh antara budaya organisasi terhadap kinerja pegawai pada CV. Sriwijaya Utama. Penelitian ini menggunakan metode analisis kualitatif dan kuantitatif. Pengumpulan data penelitian menggunakan teknik populasi dari seluruh pegawai pada CV. Sriwijaya Utama berjumlah 49 orang. bahwa persentase persentase sumbangan perubahan variabel independen budaya organisasi (X) terhadap variabel dependen kinerja $(\mathrm{Y})$ sebesar 97,8\% dan sisanya dipengaruhi faktor lain. Uji hipotesis parsial melalui uji t test diperoleh nilai $\mathrm{t}$ hitung budaya organisasi terhadap kinerja sebesar 45,893 dan $\mathrm{t}_{\text {hitung }}=45,893>\mathrm{t}_{\text {tabel }}$ 1,678 maka Ho ditolak dan Ha diterima. Dengan demikian berarti bahwa ada pengaruh budaya organisasi terhadap kinerja pegawai pada CV. Sriwijaya Utama.
\end{abstract}

Kata kunci: Budaya, Kinerja, Organisasi, Pegawai.

\section{PENDAHULUAN}

Pada masa perkembangan teknologi dewasa ini, mempunyai peranan yang sangat penting karena kinerja dari seorang karyawan mempengaruhi faktor yang lain. Menyadari bahwa manusia adalah faktor penentu yang sangat penting dan menjadi pusat perhatian dari setiap kegiatan operasionalnya maka setiap organisasi dituntut mengelola sumber daya manusia yang ada agar tujuan yang diharapkan dapat tercapai. Pada dasarnya, kemampuan berfikir dan kemampuan mental yang handal dalam bertindak merupakan potensi yang telah ada pada manusia.

Organisasi merupakan kesatuan sosial yang dikoordinasikan secara sadar dengan sebuah batasan yang relatif dapat diidentifikasikan, bekerja secara terus menerus untuk mencapai tujuan (Robbins, 2006). Akibat terjadinya interaksi dengan karakteristik masing-masing serta banyak kepentingan yang membentuk gaya hidup, pola perilaku, dan etika kerja, yang kesemuanya akan mencirikan kondisi suatu organisasi. Sehingga setiap individu dalam organisasi tidak lepas dari hakekat nilainilai budaya yang dianutnya, yang pada akhirnya akan bersinergi dengan perangkat organisasi, teknologi, system, strategi dan gaya hidup kepemimpinan. Sehingga pola interaksi sumber daya manusia dalam berorganisasi harus diseimbangkan dan diselaraskan agar organisasi dapat tetap eksis.

Budaya organisasi adalah seperangkat nilai yang mengendalikan interaksi antara suatu individu dalam organisasi dengan individu lain dalam organisasi, atau organisasi lain sebagai pemasok, dan anggota masyarakat yang dilayani. Budaya organisasi dibentuk oleh para individu dalam organisasi, etika organisasi yang dianut, hak kepegawaian yang diberikan kepada tiap pegawai dan juga jenis struktur 
organisasi itu sendiri. Budaya organisasi juga membentuk dan mengendalika perilaku dalam keorganisasiaan. Budaya organisasi mempengaruhi cara individu merespon dan menafsirkan segala situasi dan permasalahan yang dihadapi.

Budaya organisasi merupakan kumpulan nilai yang dianut dalam organisasi dan mendasari bagaimana mengelola organisasi tersebut. Nilai-nilai itu merupakan keyakinan yang dipegang teguh dan kadang-kadang tidak terungkap. Budaya organisasi berpengaruh pada perilaku anggota atau individu serta kelompok di dalam suatu organisasi dan perilaku tersebut berpengaruh pada pencapaian prestasi sehingga secara bersama-sama akan berpengaruh pada efektif atau tidaknya pencapaian organisasi (Pabundu, 2006).

Menurut (Simanjuntak, 2011) kinerja adalah tingkat pencapaian hasil atas pelaksanaan tugas tertentu. Kinerja organisasi adalah tingkat pencapaian hasil dalam rangka mewujudkan tujuan organisasi. Manajemen kinerja adalah keseluruhan kegiatan yang dilakukan untuk meningkatkan kinerja organisasi, termasuk kinerja masing-masing individu dan kelompok kerja di organisasi tersebut. Kinerja individu, kinerja kelompok dan kinerja organisasi, dipengaruhi oleh banyak faktor intern dan ekstern organisasi.

Dalam upaya pengembangan organisasi dalam rangka mendukung tercapainya tujuan organisasi, umumnya setiap organisasi mengalami hambatan dalam menempatkan karyawan sesuai dengan ungkapan 'The Right Man On the right Place" maka paling tidak sebuah organisasi membutuhkan suatu perangkat organisasi antara lain struktur organisasi disertai penelitian pekerjaan yang dilengkapi dengan spesifikasi serta persyaratan jabatan atau pekerjaannya.

Seorang karyawan apabila ahli pada posisinya maka ia bekerja dengan baik dan dapat menyelesaikan pekerjaannya dengan baik. Hal ini tentu akan menguntungkan bagi perusahaan maupun karyawan tersebut. Dipihak perusahaan akan mendapatkan keuntungan yang dicapai, dipihak karyawan ia akan merasa puas dapat menyelesaikan tugas dan kewajiban dengan baik. Tingkat kepuasan kerja pada dasarnya merupakan hal yang bersifat individual. Masing-masing individu mempunyai tingkat kepuasan yang berbeda. Kepuasan kerja merupakan penilaian pekerjaan yaitu seberapa jauh pekerjaannya secara keseluruhan memuaskan kebutuhan. Kepuasan kerja dapat dilihat dari tingkat absensi. Para karyawan yang kurang mendapat kepuasan kerja akan malas bekerja atau kurang disiplin dan cenderung lebih sering absen, demikian pula sebaliknya karyawan yang memperoleh kepuasan kerja menjadi lebih bersemangat tingkat absensi akan lebih kecil.

Tingkat absensi yang masih cukup tinggi, karena standar maksimum tingkat absensi yang ditetapkan oleh perusahaan adalah dua persen. Semakin tinggi tingkat absensi semakin besar kerugian yang diderita perusahaan. Pada bulan Februari tingkat absensi menunjukkan angka tertinggi, yaitu 4,09\%. Apabila hal ini dibiarkan tentu akan mempengaruhi tingkat pencapaian target perusahaan.

Kenaikan absensi yang cukup besar merupakan indikasi rendahnya disiplin kerja, sehingga berpengaruh pada kinerja kerja karyawan. Dalam kaitannya dengan kinerja karyawan, itu akan membuat semangat kerja karyawan yang dapat mengakibatkan menurunnya kinerja karyawan, hal tersebut seharusnya segera dibenahi agar para pimpinan.

Berdasarkan uraian tersebut diatas, maka peneliti tertarik untuk mengadakan penelitian dengan judul: "Pengaruh Budaya Organisasi terhadap Kinerja Karyawan Pada CV. Sriwijaya Utama Di Bandar Lampung" 


\section{KAJIAN TEORI}

\section{Definisi Budaya Organisasi}

Menurut (Robbins dan Judge, 2008) Ide untuk memandang organisasi sebagai kultur - dimana terdapat sebuah sistem makna yang dimiliki bersama oleh para anggotanya - merupakan sebuah fenomena yang relatif baru. Sedangkan menurut (Laudon dan Laudon, 2012) Seluruh organisasi memiliki asumsi dasar, yang tak dapat dibantah, dan tidak dapat dipertanyakan (oleh anggotanya) yang menjelaskan tujuan dan produk organisasi tersebut. Budaya organisasi meliputi seperangkat asumsi ini mengenai produk apa yang harus diproduksi organisasi, bagaimana organisasi memproduksinya, dimana dan untuk siapa.

Dengan demikian, sebuah organisasi yang telah mempunyai sistem makna yang dimiliki bersama oleh para anggotanya, mempunyai asumsi dasar yang menjelaskan tujuan organisasi tersebut, dapat dikatakan bahwa organisasi tersebut telah memiliki budaya organisasi. Budaya organisasi terdiri dari 2 kata yaitu budaya dan organisasi.

Menurut (Rivai dan Mulyadi, 2012) pengertian budaya menurut definisi, budaya itu sukar dipahami, tidak berwujud, implisit dan dianggap sudah semestinya atau baku. Definisi lain menyebutkan budaya adalah sejumlah pemahaman penting seperti norma, nilai, sikap, dan keyakinan yang dimiliki bersama oleh anggota organisasi. Menurut (Laudon dan Laudon, 2012) bahwa organisasi adalah struktur formal yang stabil dan formal yang mengambil sumber daya dari lingkungan dan memprosesnya untuk menciptakan output. Dari penggabungan 2 kata yaitu budaya dan organisasi, maka menjadi budaya organisasi yang memiliki definisi atau arti tersendiri.

Menurut (Robbins dan Judge, 2008) bahwa Kultur organisasi (organizational culture) mengacu pada sebuah sistem makna bersama yang dianut oleh para anggota yang membedakan organisasi tersebut dengan organisasi lainnya. Menurut (Rivai dan Mulyadi, 2012), menyatakan bahwa budaya organisasi adalah suatu kerangka kerja yang menjadi pedoman tingkah laku sehari-hari dan membuat keputusan untuk karyawan dan mengarahkan tindakan mereka untuk mencapai tujuan organisasi.

Laudon dan Laudon, 2012) menyatakan bahwa budaya organisasi adalah kekuatan pengikat yang kuat yang menghambat konflik politik dan mendorong pemahaman yang sama, perjanjian pada prosedur, dan praktik umum. Menurut (Tintami et al. 2012) bahwa budaya organisasi adalah filosofi dasar organisasi yang memuat keyakinan, norma-norma, dan nilai-nilai bersama yang menjadi karekteristik inti tentang bagaimana melakukan sesuatu dalam organisasi. Keyakinan, norma-norma, dan nilai-nilai tersebut menjadi pegangan semua sumber daya manusia dalam organisasi dalam melaksanakan kinerjanya (Wibowo, 2011).

Dari beberapa pendapat tersebut diatas, maka dapat ditarik sebuah kesimpulan bahwa "budaya organisasi adalah suatu nilai-nilai yang diyakini (belief) dan merupakan sistem dalam suatu organisasi yang mendukung dalam pelaksanaan kegiatan dalam berorganisasi yang mempunyai ciri-ciri tertentu untuk mencapai tujuan yang telah disepakati bersama".

\section{Fungsi Budaya Organisasi}

Keberadaan budaya organisasi dalam suatu perusahaan atau organisasi tidak hanya sekedar slogan saja namun mempunyai fungsi dan manfaatnya. Banyak perusahaan membuat atau mendisain budaya organisasi dengan mengeluarkan uang miliaran rupiah. Tujuannya agar 
organisasi tersebut memiliki budaya organisasi yang kuat sehingga dapat menjadi landasan dalam mencapai tujuan organisasi.

(Menurut Robbins dan Judge, 2008) kultur memiliki sejumlah fungsi dalam sebuah organisasi, yaitu:

1. Penentu batas-batas, artinya budaya menciptakan perbedaan atau distingsi antara satu organisasi dengan organisasi lainnya.

2. Memuat rasa identitas anggota organisasi.

3. Memfasilitasi lahirnya komitmen terhadap sesuatu yang lebih besar dari pada kepentingan individu.

4. Meningkatkan kestabilitas sistem sosial, kultur adalah perekat sosial yang membantu menyatukan organisasi dengan cara menyediakan standar mengenai apa yang sebaiknya dikatakan dan dilakukan oleh pegawai.

5. Kultur mendefinisikan aturan main: Dalam definisinya, bersifat samar, tanmaujud, implisit, dan begitu adanya.

\section{Dampak Budaya Organisasi}

Menurut (Rivai dan Mulyadi, 2012) budaya mempunyai dampak yang kuat dan semakin besar pada prestasi kerja organisasi, diantaranya, yaitu:

1. Budaya perusahaan dapat mempunyai dampak signifikan pada prestasi kerja ekonomi perusahaan dalam jangka panjang.

2. Budaya perusahaan bahkan mungkin merupakan faktor yang lebih penting dalam menentukan sukses atau gagalnya perusahaan dalam masa mendatang.
3. Budaya perusahaan yang menghambat prestasi keuangan yang kokoh dalam jangka panjang sering terjadi dan budaya tersebut berkembang dengan mudah.

4. Walaupun sulit untuk diubah, budaya perusahaan dapat dibuat untuk lebih meningkatkan prestasi.

\section{Faktor-Faktor yang Mempengaruhi Kinerja}

Kinerja seorang pegawai dapat dipengaruhi berbagai faktor, baik faktor eksternal maupun internal dari pegawai tersebut. Simamora dalam (Mangkunegara, 2012) mengatakan bahwa kinerja pada umum nya dipengaruhi oleh tiga faktor, yaitu:

a. Faktor individual yang terdiri dari:

1. Kemampuan dan keahlian

2. Latar belakang

3. Demografi

b. Faktor psikologis yang terdiri dari:

1. Persepsi

2. Kelakuan (Attitude)

3. Sifat (Personality)

4. Pembelajaran

5. Motivasi

c. Faktor organisasi yang terdiri dari:

1. Sumber daya

2. Kepemimpinan

3. Penghargaan

4. Struktur

5. Job Design.

\section{METODE PENELITIAN}

\section{Objek Penelitian}

Objek penelitian adalah CV. Sriwijaya Utama yang berlokasi di Jalan Pangeran Emir M. Noor No. 103 Bandar Lampung. 
Penelitian dilaksanakan pada bulan April 2017.

\section{Metode dan Teknik Pengumpulan Data}

Dalam penelitian ini jenis data yang diperlakukan adalah :

a. Data Primer

Data primer merupakan data dasar yang akan diperoleh langsung tanpa perantara orang atau lembaga lain sebagai pihak ketiga. Data primer ini diperoleh dengan wawancara melalui responden dengan menggunakan daftar pertanyaan.

b. Data Sekunder

Data skunder merupakan data yang diperoleh melalui orang lain yang berhubungan dengan permasalahan yang dipecahkan. Data sekunder ini diperoleh melalui cara studi dokumenter yaitu mengumpulkan dan mempelajari brosur-brosur serta dokumen organisasi.

Teknik pengumpulan data yang akan dilakukan oleh peneliti sebagai upaya untuk melengkapi data dalam penelitian meliputi:

1. Interview (Wawancara)

Wawancara langsung/tanya jawab dengan para pegawai untuk memperoleh data mengenai masalah yang menjadi objek penelitian.

2. Studi Dokumentasi

Mempelajari data-data dan dokumen yang ada hubungannya dengan masalah yang diteliti.

\section{Observasi}

Pengamatan secara langsung terhadap objek penelitian, sehingga memungkinkan dapat melihat objek yang sebenarnya.
4. Kuesioner

Seperangkat pernyataan yang disusun untuk diajukan kepada responden agar memperoleh informasi tertulis dari responden berkaitan dengan variabel penelitian.

\section{Sampel dan Populasi}

Menurut Dr. Suharsimi Arikunto dalam bukunya prosedur Penelitian Suatu Pendekatan Praktek sebagai berikut apabila dalam suatu penelitian terhadap subjek yang kurang dari 100, maka diambil semua (populasi) sedangkan apabila subjek lebih dari 100 maka sampel yang diambil antara $10 \%-15 \%$ atau $20 \%, 25 \%$ atau lebih, dari seluruh populasi yang ada (Arikunto, 2011). Jadi penelitian ini adalah teknik populasi karena Jumlah subjek dalam penelitian ini yang penulis ambil yaitu berjumlah 49 orang responden yaitu keseluruhan dari jumlah karyawan.

\section{Metode Analisis Data}

Analisis Kualitatif Yaitu pemecahan permasalahan yang dilakukan dengan cara membandingkan antara teori dengan praktek yang dilakukan pada objek penelitian. Analisis kuantitatif yaitu menganalisis dengan menggunakan angka angka yang dihimpun dari data perusahaan yang berkaitan dengan permasalahan yang dihadapi instansi. Dalam analisis kuantitatif, menggunakan perhitungan dengan pendekatan rumus Regresi linier Sederhana.

Persamaan Regresi Linear Sederhana menentukan persamaan regresi linear sederhana untuk X :

$$
Y=a+b X+e
$$

Keterangan:

$$
\begin{aligned}
\mathrm{Y} & =\text { Kinerja pegawai } \\
\mathrm{a} & =\text { Konstanta }
\end{aligned}
$$


$\mathrm{b}=$ Koefisien regresi $\mathrm{X}$

$\mathrm{X}=$ Budaya Organisasi

$\mathrm{e}=$ Faktor kesalahan

Untuk mengetahui besarnya pengaruh, penghitungan koefisien korelasi tersebut kemudian dilanjutkan dengan Rumus Koefisien Determinasi atau Koefisien Penentu (KP):

$$
K P=(r)^{2} x 100 \%
$$

Untuk menguji secara hipotesis secara parsial digunakan Uji t dengan rumus :

$$
t_{\text {hitung }}=\frac{r \sqrt{N-2}}{\sqrt{1-r^{2}}}
$$

Keterangan:

$$
\begin{array}{ll}
\mathrm{t}_{\text {hitung }} & =\text { Nilai } \mathrm{t} \\
\mathrm{r} & =\text { Koefisien Korelasi } \\
\mathrm{N} & =\text { Jumlah responden }
\end{array}
$$

Kriteria untuk Uji $\mathrm{t}$ adalah sebagai berikut :

a) Jika $t_{\text {hitung }}>t_{\text {tabel }}$ maka Ha diterima dan Ho ditolak.

b) Jika $t_{\text {hitung }} \leq \mathrm{t}_{\text {tabel }}$ maka Ha ditolak dan Ho diterima.

\section{HASIL DAN PEMBAHASAN}

\section{Uji Validitas dan Uji Reliabilitas}

Data penelitian yang telah dikumpulkan kemudian diolah untuk menguji kualitas data berupa uji validitas dan reliabilitas. Dengan demikian dapat diinterprestasikan bahwa setiap item indikator instrumen masing-masing variabel tersebut valid. Pengujian dilakukan dengan menggunakan Microsoft Excel 2007. Berdasarkan pengujian validitas dari masing-masing variabel yaitu 10 pernyataan untuk variabel Independent (X) dan variabel (Y) jawaban responden telah memiliki validitas yang cukup baik.

Berdasarkan hasil uji reliabilitas didapat nilai Alpha Budaya Organisasi (X) sebesar 0,834 dan dapat disimpulkan bahwa kuesioner yang digunakan dalam penelitian ini dinyatakan reliabel karena alpha-nya sebesar 0,834 > 0,60. Ini berarti bahwa alat ukur yang digunakan dalam penelitian ini sudah memiliki kemampuan untuk memberikan hasil pengukuran yang konsisten dalam mengukur gejala yang sama.

\section{Analisis Kuantitas}

Berdasarkan hasil perhitungan tingkat korelasi antara variabel diperoleh besarnya tingkat korelasi antara variabel Budaya Organisasi (X) dengan variabel Kinerja (Y) pada CV. Sriwijaya Utama adalah sebesar 0,989. Jika dikonsultasikan dengan tabel Kriteria Pengukuran hubungan Koefisien Korelasi (Sudjana 1999) maka tingkat korelasi Budaya Organisasi (X) dengan variabel kinerja (Y) pada DPRD Provinsi Lampung dalam kategori korelasi "sangat tinggi” terletak pada $(0,91-1,00)$.

Koefisien Determinasi (KD) Budaya Organisasi (X) terhadap Kinerja (Y) adalah $\mathrm{R}^{2}=0,978 \times 100 \%=97,8 \%$. Hal ini menunjukkan bahwa variabel budaya organisasi (X) menjelaskan perubahan terhadap variabel Kinerja (Y) sebesar $97,8 \%$, sedangkan sisanya dijelaskan oleh faktor lain yang tidak dikaji dalam penelitian ini. Standard Error of Estimate adalah suatu ukuran banyaknya kesalahan model regresi dalam memprediksikan nilai $\mathrm{X}$. Dari hasil regresi didapat nilai 0,707.

Berdasarkan hasil uji $\mathrm{t}$ didapat nilai $t_{\text {hitung }}=45,893$. Apabila dibandingkan dengan $\mathrm{t}_{\text {tabel }}(\mathrm{df}=\mathrm{n}-2)$ pada taraf signifikan yaitu 1,678 , maka $t_{\text {hitung }}=45,893<\mathrm{t}_{\text {tabel }}=$ 1,678 sehingga dapat disimpulkan bahwa variabel Budaya Organisasi (X) berpengaruh terhadap Kinerja (Y). 
Berdasarkan kondisi tersebut, bentuk persamaan regresinya adalah $\mathrm{Y}=-1,799+$ $1,043 \mathrm{X}+$ e. Nilai koefisien budaya organisasi sebesar 1,043 menunjukkan apabila budaya organisasi meningkat sebesar 1 satuan maka kinerja juga akan meningkat sebesar 1,043 satuan.

Hasil penelitian menunjukkan bahwa budaya organisasi $(X)$ pada CV. Sriwijaya Utama dalam kategori baik. Untuk perhitungan koefisien determinasi variabel budaya organisasi pada tabel diatas diperoleh angka $\mathrm{R}^{2}$ ( $\mathrm{R}$ Square) sebesar 0,978 atau $97,8 \%$. Hal ini menunjukkan bahwa persentase sumbangan perubahan variabel independen budaya organisasi (X) terhadap variabel dependen kinerja (Y) sebesar $97,8 \%$ dan sisanya dipengaruhi faktor lain.

Uji hipotesis parsial melalui uji t test diperoleh nilai $\mathrm{t}$ hitung budaya organisasi terhadap kinerja sebesar 45,893 dan thitung $_{\text {he }}=$ $45,893>t_{\text {tabel }} 1,678$. Persamaan regresi antara budaya organisasi dan kinerja pada CV. Sriwijaya Utama adalah sebesar Y = $1,799+1,043 \mathrm{X}+\mathrm{e}$, yang menunjukkan setiap kenaikan satu satuan dari variabel budaya organisasi akan diikuti oleh naiknya variabel kinerja pada CV. Sriwijaya Utama sebesar 1,043 satuan.

\section{KESIMPULAN DAN SARAN}

\section{Kesimpulan}

Berdasarkan analisis data dan pembahasan pada bab sebelumnya, diperoleh kesimpulan bahwa hasil penelitian menunjukkan bahwa budaya organisasi (X) pada CV. Sriwijaya Utama dalam kategori baik. Untuk perhitungan koefisien determinasi variabel budaya organisasi diperoleh angka $\mathrm{R}^{2}$ ( $\mathrm{R}$ Square) sebesar 0,978 atau $97,8 \%$. Uji hipotesis parsial melalui uji $\mathrm{t}$ test diperoleh nilai $\mathrm{t}$ hitung budaya organisasi terhadap kinerja sebesar 45,893 dan $t_{\text {hitung }}=45,893>t_{\text {tabel }} 1,678$.
Persamaan regresi antara budaya organisasi dan kinerja pada CV. Sriwijaya Utama adalah sebesar $\mathrm{Y}=-1,799+1,043 \mathrm{X}+\mathrm{e}$, diketahui bahwa budaya organisasi merupakan salah satu unsur penting dalam meningkatkan kinerja.

\section{Saran}

Adapun saran-saran yang dapat penulis sampaikan adalah sebagai berikut :

1. Hendaknya pimpinan dapat memberikan mendengarkan dan mempertimbangkan pendapat dari para karyawan nya, sehingga karyawan semangat dan termotivasi dalam mengerjakan tugas yang diberikan.

2. Untuk meningkatkan kinerja karyawan, hendaknya pimpinan harus memberikan pengarahan dan bimbingan kepada karyawan nya agar dapat lebih cermat dan teliti dalam mengerjakan tugas.

3. Bagi peneliti selanjutnya hendaknya dapat menganalisis faktor- faktor lain yang berpengaruh terhadap peningkatan kinerja karyawan PT. Telkomsel Branch Lampung seperti kemampuan karyawan dan motivasi karyawan agar penelitian ini dapat lebih baik.

\section{DAFTAR PUSTAKA}

Arikunto, Suharsimi. 2012. Prosedur Penelitian, Ed Revisi V. Jakarta: Rineka Cipta.

Ghozali, Imam. 2009. Aplikasi Analisis Multivariate dengan Program SPSS. Ed Keempat. Semarang: UNDIP.

Laudon, Kenneth C. dan Laudon, Jane P. 2012. Sistem Informasi Manajemen, Mengelola Perusahaan Digital, 
Buku 1 Edisi 10. Jakarta: Salemba Empat.

Lunenburg, Fred C. 2011. Organizational Culture-Performance Relationships: Views of Excellence and Theory Z. National Forum of Educational Administration And Supervision Journal. VoL. 29, No.04. Pp 1-9.

Mangkunegara, AA. Prabu. 2009. Manajemen Sumber Daya Manusia Perusahaan. Cetakan ke sembilan. Bandung: PT. Remaja Rosdakarya.

Mathis, Robert. L \& Jackson. H. 2006. Manajemen Sumber Daya Manusia, Edisi 10. Jakarta: Salemba Empat.

Notoadmojo, $\quad$ Soekidjo. 2009. Pengembangan Sumber Daya Manusia. Cetakan keempat. Jakarta: Rineka Cipta.

Rahma, S., Suhandana, G.A., dan Suarni, Ni Kt. 2013. Kontribusi Efektivitas Kepemimpinan, Budaya Organisasi Dan Etos Kerja Terhadap Kepuasan Kerja Pegawai Balai Diklat Keagamaan Denpasar. e-Journal Vol.04. Pp 1-12.

Rivai, Veithzal. dan Mulyadi, Deddy. 2012. Kepemimpinan dan Perilaku Organisasi. Edisi Ketiga. Jakarta: PT. Raja Grafindo Persada.

Robbins, Stephen P. dan Judge, Timothy A. 2008. Perilaku Organisasi, Buku 2. Jakarta: Salemba Empat.

Sedarmayanti. 2011. Manajemen Sumber Daya Manusia dan Manajemen PNS. Cetakan Kelima. Bandung: PT. Refika Aditama.
Siagian, Sondang P. 2001. Manajemen Sumber Daya Manusia. Jakarta: Gunung Agung.

Stephen P. Robbins. 2008. Manajemen Edisi-7, Jilid 1, Edisi Bahasa Indonesi. Jakarta: PT. Indeks.

Sudjana. 2009. Metode Statistik I dan II. Yogyakarta: Penerbit FP UGM.

Sugiyono. 2009. Metode Penelitian Kuantitatif, Kualitatif, dan $R \& D$. Bandung: Alfabeta.

Tintami, Lila., Pradhanawati, Ari., dan Susanto, Hari. 2012. Pengaruh Budaya Organisasi Dan Gaya Kepemimpinan Transformasional Terhadap Kinerja Karyawan Melalui Disiplin Kerja Pada Karyawan Harian SKT Megawon II PT. Djarum Kudus. e-Journal. Vol. 02, No.01. Pp 1-8.

Tika. 2006. Budaya Organisasi dan Peningkatan Kinerja Perusahaan. Jakarta: Bumi Aksara.

Wibowo. 2010. Manajemen Kinerja. Edisi ketiga. Jakarta: Rajawali Pers. 